\title{
The WT1 Wilms' tumor suppressor gene product interacts with estrogen receptor- $\alpha$ and regulates IGF-I receptor gene transcription in breast cancer cells
}

\author{
Naama Reizner, Sharon Maor, Rive Sarfstein, Shirley Abramovitch, Wade V Welshons ${ }^{1}$, \\ Edward M Curran ${ }^{1}$, Adrian V Lee ${ }^{2}$ and Haim Werner \\ Department of Clinical Biochemistry, Sackler School of Medicine, Tel Aviv University, Tel Aviv 69978, Israel \\ ${ }^{1}$ Department of Veterinary Biomedical Sciences, University of Missouri, Columbia, Missouri 65211, USA \\ ${ }^{2}$ Department of Medicine, Baylor College of Medicine, Houston, Texas 77030, USA
}

(Requests for offprints should be addressed to H Werner; Email: hwerner@post.tau.ac.il)

\begin{abstract}
The IGF-I receptor (IGF-IR) has an important role in breast cancer development and progression. Previous studies have suggested that the IGF-IR gene is negatively regulated by a number of transcription factors with tumor suppressor activity, including the Wilms' tumor protein WT1. The present study was aimed at evaluating the hypothesis that IGF-IR gene transcription in breast cancer cells is under inhibitory control by WT1 and, furthermore, that the mechanism of action of WT1 involves functional and physical interactions with estrogen receptor- $\alpha(E R \alpha)$. Results of transient coexpression experiments showed that all four predominant isoforms of WT1 (including or lacking alternatively spliced exons 5 and 9) repressed IGF-IR promoter activity by 39-49\%. To examine the potential interplay between WT1 and ER $\alpha$ in control of IGF-IR gene transcription we employed ER-depleted C4 cells that were generated by clonal selection of ER-positive MCF-7 cells that were maintained in estrogen-free conditions. IGF-IR levels in C4 cells were $\sim 43 \%$ of the values in MCF-7 cells whereas WT1 levels in C4 cells were $4 \cdot 25$-fold higher than in MCF-7. Triple cotransfection experiments using an ER $\alpha$ expression vector in the absence or presence of WT1 expression vectors, along with an IGF-IR promoter reporter plasmid, revealed that ER $\alpha$ stimulated IGF-IR promoter activity whereas coexpression of WT1 abrogated the effect of ER $\alpha$. In addition, co-immunoprecipitation experiments demonstrated a specific association between WT1 and ER $\alpha$. Combined, our results suggest that WT1 suppresses IGF-IR gene transcription in breast cancer cells via a mechanism that involves protein-protein association with ER $\alpha$. As a result of this interaction, the ability of ER $\alpha$ to transactivate the IGF-IR promoter is abrogated. These findings are consistent with a potential tumor suppressor role for WT1 in breast cancer and suggest that WT1 inactivation in tumoral cells may result in deregulated IGF-IR gene expression and enhanced mitogenic activation by locally produced and/or circulating IGFs.
\end{abstract}

Journal of Molecular Endocrinology (2005) 35, 135-144

\section{Introduction}

The involvement of the insulin-like growth factor (IGF) system in the biology of breast cancer has been well established (Surmacz 2000, Yee \& Lee 2000). Evidence of both an experimental and a clinical nature identified IGF-I and IGF-II as major players in mammary gland growth and development as well as in breast cancer initiation and progression. In addition, a number of epidemiological surveys demonstrated a positive correlation between circulating IGF-I concentrations and relative risk of breast cancer in premenopausal women (Hankinson et al. 1998, Pollak 2000). The biological actions of both endocrine and locally produced IGF-I and IGF-II on breast cell proliferation, survival and transformation are mediated by the IGF-I receptor (IGF-IR) (LeRoith et al. 1995, Werner \& LeRoith 1996,
Baserga 1999). Ligand-induced phosphorylation of the IGF-IR tyrosine kinase domain leads to the activation of a number of cytoplasmic signal transduction molecules, including the ras-raf-MAPK and PI3-PKB/Akt cascades.

Consistent with its antiapoptotic, cell-survival promoting role, most available evidence supports the notion that the IGF-IR gene is highly expressed in many types of cancer, including breast tumors (Happerfield et al. 1997, Mitsiades et al. 2004). Accordingly, IGF-IR overexpression in breast tissue was linked to tumor recurrence at the primary site and radioresistance (Turner et al. 1997). Interestingly, immunohistochemical analyses revealed that progression to advanced metastatic stages was associated with a significant decrease in IGF-IR levels (Schnarr et al. 2000). Combined, these results suggest that normal breast epithelial cells respond 
to endocrine and autocrine/paracrine IGFs to maintain an appropriate balance between proliferation and differentiation. Excess IGF may increase the probability that cells become premalignant while transition to advanced-stage disease appears to be associated with a reduction in IGF-IR concentrations and IGF responsiveness (Pennisi et al. 2002). The molecular mechanisms that are responsible for regulation of IGF-IR gene expression in breast cancer cells remain to be identified.

The regulatory region of the IGF-IR gene comprises a unique 'initiator' motif, from which transcription is initiated in vivo, and which acts in concert with upstream Spl sites (Werner et al. 1992, Beitner-Johnson et al. 1995). The region flanking the transcription start site is extremely G-C rich, with no obvious TATA or GAAT elements. In addition, the IGF-IR promoter contains numerous binding sites for members of the early growth response (EGR) family of transcriptional activators (Werner et al. 1993, 1994). The EGR family includes, among other members, EGR1 (NGFI-A, Zif 268, Krox 24), EGR2, EGR3 and the Wilms' tumor suppressor gene, WT1 (Call et al. 1990, Gessler et al. 1990, Rauscher 1993). The WT1 gene is located on chromosome $11 \mathrm{p} 13$ and encodes a DNA-binding protein with a proline- and glutamine-rich $\mathrm{N}$-terminal end and four zinc-finger domains in its C-terminus (Morris et al. 1991). The WT1 gene undergoes alternative splicing at two different positions, a $51 \mathrm{bp}$ sequence encoded by exon 5 and a 9 bp sequence that results from the use of an alternative $5^{\prime}$ splice junction in exon 9. Use of exon 5 results in isoforms that include a 17 amino acid insert while use of exon 9 leads to the inclusion of a tripeptide (Lys-Thr-Ser, KTS) between zinc-fingers 3 and 4 (Haber et al. 1991) (Fig. 1A). The consensus binding sequence for the EGR/WT1 gene products is $5^{\prime}$-GGGGGG GCG-3' (Rauscher et al. 1990). Unlike other members of the EGR family, WT1 has been shown to usually repress the activity of target promoters containing this cis-element, including the IGF-II, platelet-derived growth factor A-chain, transforming growth factor- $\beta 1$ and others (Madden et al. 1991, Drummond et al. 1992, Gashler et al. 1992, Dey et al. 1994). Inactivation of the WT1 gene has been postulated to be a key event in the etiology of Wilms' tumor, a pediatric kidney cancer (Call et al. 1990, Rose et al. 1990).

In the specific context of the IGF-IR gene, we have previously demonstrated that WT1 isoforms lacking the KTS insert suppressed IGF-IR promoter activity in a number of cell types, including osteosarcoma- and colorectal cancer-derived cell lines (Werner et al. 1993, 1994, 1995, Idelman et al. 2003). Furthermore, the biological activity of WT1 isoforms lacking KTS was associated with specific binding to cis-elements in the IGF-IR promoter region, as demonstrated using electrophoretic mobility shift assays (EMSAs) and DNaseI footprinting analysis. Isoforms including the
KTS tripeptide were impaired in their ability to bind to the IGF-IR promoter region and, therefore, displayed a reduced repressing activity.

Recent studies have suggested a potential role for WT1 in various aspects of mammary gland biology. Thus, the involvement of WT1 in mammary gland morphogenesis was inferred from immunohistochemical analyses showing that WT1 is differentially regulated between developmentally divergent ducts and lobules as well as within the mature duct (Silberstein et al. 1997). With regard to breast tumorigenesis, a number of observations suggested that WT1 may function as a candidate tumor suppressor. Specifically: (i) a high percentage of breast cancer cells lacked immunodetected WT1; (ii) the cytoplasmic localization of WT1 suggested that functional inactivation of WT1 occurs in a subset of tumors; (iii) changes in the intracellular localization of WT1 accompanied tumor progression; and (iv) common tumor-associated perturbations of WT1 mRNA splicing were demonstrated (Silberstein et al. 1997).

In view of the important role of IGF-IR in breast cancer etiology and to extend our previous observations on regulation of IGF-IR gene expression by WT1, we investigated the potential involvement of WT1 in transcriptional control of the IGF-IR gene in breast cancer cells. Specifically, our aim was to elucidate the mechanisms that are responsible for regulation of the IGF-IR gene, a bona fide WT1 downstream target, in mammary gland-derived cells, and to evaluate the potential molecular interactions between WT1 and breast cell-specific transactivators. The results obtained indicate that WT1 suppresses IGF-IR gene transcription via a mechanism that involves protein-protein interaction with estrogen receptor- $\alpha(\mathrm{ER} \alpha)$. These results are consistent with a tumor suppressor role for WT1 in breast cancer cells and suggest that WT1 inactivation in tumoral cells may lead to deregulated IGF-IR expression and enhanced proliferative capacity.

\section{Materials and methods}

\section{Cell cultures}

Breast carcinoma-derived MCF-7 cells were obtained from the American Type Culture Collection (Mannassas, VA, USA). C4 cells were generated by clonal selection of MCF-7 cells cultured in estrogen-free medium for 9 months (Oesterreich et al. 2001). C4 cells were grown in phenol red-free Dulbecco's modified Eagle's medium (DMEM) supplemented with 10\% charcoal-stripped fetal bovine serum (FBS), $2 \mathrm{mM}$ glutamine, $50 \mu \mathrm{g} / \mathrm{ml}$ gentamicin sulfate and $2.5 \mu \mathrm{g} / \mathrm{ml}$ Fungizone. MCF-7 cells were cultured in DMEM containing 10\% FBS, glutamine and antibiotics. 


\section{Plasmids and transfections}

For cotransfection experiments an IGF-IR promoterluciferase reporter construct, $\mathrm{p}(-476 /+640) \mathrm{LUC}$, was employed. The $\mathrm{p}(-476 /+640)$ LUG plasmid, containing $476 \mathrm{bp}$ of the $5^{\prime}$-flanking and $640 \mathrm{bp}$ of the 5 -untranslated regions of the rat IGF-IR gene, includes 12 cis-elements for transcription factor WT1. The location and binding affinities of the WT1 sites have been previously described (Werner et al. 1994). The construction of WT1 expression plasmids (WT1 $+/+$, $+/-,-/+$ and $-/-)$ containing or lacking the alternatively spliced 17 amino acid exon 5-encoded sequence and the three amino acid exon 9-encoded fragment (KTS) has been previously reported (Tajinda et al. 1999) (Fig. 1A). WT1 expression vectors were provided by Dr C T Roberts Jr (Oregon Health Sciences University, Portland, OR, USA). A WT1 promoter luciferase reporter plasmid, pGLWTpS-P, including nucleotides -873 to +425 (relative to the major transcription start site), was provided by Dr M Eccles (University of Otago, Dunedin, New Zealand) (McConnell et al. 1997). An ER $\alpha$ expression vector was provided by Dr Y Koch (Weizmann Institute of Science, Rehovot, Israel).

Cells were seeded in six-well plates the day before transfection. MCF-7 cells were transfected with $1 \mu \mathrm{g}$ IGF-IR reporter plasmid and 0.5 $\mu \mathrm{g}$ WT1 expression vector (or empty pcDNA3), along with $0.2 \mu \mathrm{g}$ $\beta$-galactosidase expression plasmid (pCMV $\beta$; Clontech, Palo Alto, CA, USA), using the jetPEI reagent (Polyplus Transfection, Illkirch, France). Cells were harvested $48 \mathrm{~h}$ after transfection, and luciferase and $\beta$-galactosidase activities were measured as previously described (Werner et al. 1993).

\section{Western immunoblots}

Cells were serum-starved overnight and then treated with increasing concentrations of estradiol (SigmaAldrich Corp.) for $24 \mathrm{~h}$. Following incubation, cells were harvested and lysates were prepared as described previously (Idelman et al. 2003). Samples were subjected to $8 \%$ SDS-PAGE, followed by electrophoretic transfer of the proteins to nitrocellulose membranes. After blocking with $3 \%$ milk in T-TBS $(20 \mathrm{mM}$ Tris-HCl, $\mathrm{pH}$ $7 \cdot 5,135 \mathrm{mM} \mathrm{NaCl}$ and $0 \cdot 1 \%$ Tween-20), blots were incubated with a polyclonal antibody against WT1 (C-19; Santa Cruz Biotechnology, Santa Cruz, CA, USA), washed extensively with T-TBS containing $0 \cdot 2 \%$ milk, and incubated with an horseradish peroxidaseconjugated secondary antibody. Proteins were detected using the SuperSignal West Pico Chemiluminescent Substrate (Pierce, Rockford, IL, USA). In addition, membranes were blotted with anti-tubulin as a loading control.
(A)

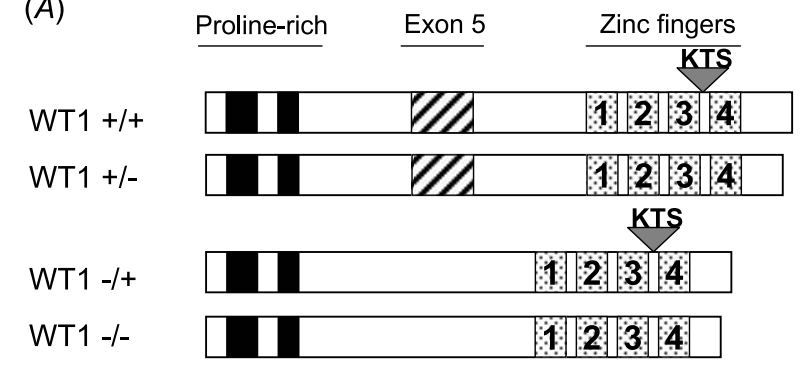

(B)

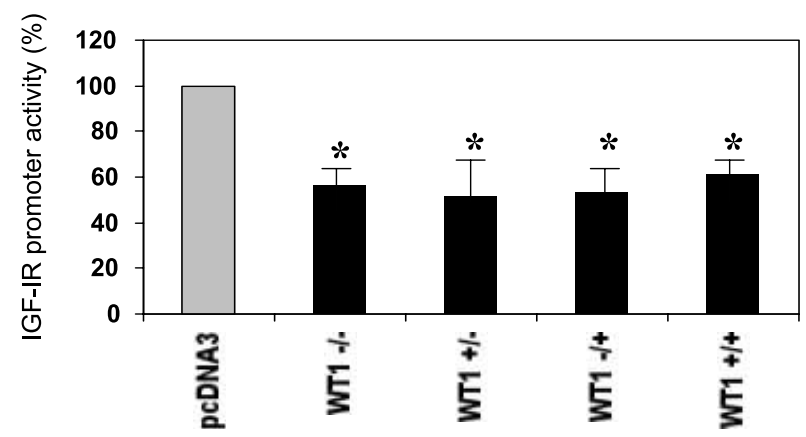

Figure 1 Transcriptional regulation of the IGF-IR promoter by WT1 isoforms in breast cancer-derived cells. (A) Schematic representation of WT1 isoforms. The primary transcript of the WT1 gene is subject to alternative splicing of two different sequences, a $51 \mathrm{bp}$ sequence encoded by exon 5 and a $9 \mathrm{bp}$ sequence that results from the use of an alternative $5^{\prime}$ splice junction in exon 9. The WT1 isoform that includes both the exon 5-encoded sequence and the exon 9-encoded Lys-Thr-Ser (KTS) tripeptide is designated WT1 $+/+$. The isoform designated WT1 -/-lacks both sequences. WT1 +/-includes the 17 amino acid exon 5-encoded sequence but lacks the KTS tripeptide, and isoform WT1 -/+ lacks the 17 amino acid insert and contains KTS. (B) MCF-7 cells were cotransfected with $1 \mu \mathrm{g}$ $\mathrm{p}(-476 /+640)$ LUC IGF-IR promoter luciferase reporter plasmid, together with $0.5 \mu \mathrm{g}$ of expression vectors encoding each of the four isoforms of WT1 (WT1 $-/-,+/-,-/+$ or $+/+$ ), along with $0.2 \mu \mathrm{g} \mathrm{pCMV} \beta$, using the jetPEI transfection reagent. Luciferase and $\beta$-galactosidase activities were measured after $48 \mathrm{~h}$. Luciferase data were normalized for $\beta$-galactosidase; $100 \%$ represents the IGF-IR promoter-driven luciferase activity in the absence of WT1. Bars are means \pm S.E.M. of three experiments, performed in duplicate dishes. ${ }^{\star} P<0.05$ vs control.

\section{RT-PCR}

Total RNA was prepared from estradiol-treated cultures using the AquaPure RNA isolation kit (Bio-Rad, Hercules, CA, USA). WT1 mRNA levels were measured by semiquantitative RT-PCR, using the following primers: sense, 5'-CTGGAATCAGATGAACTTAGG-3'; antisense, 5'-ACGTGTATGAGTCGTGGTG-3' (Dong et al. 1997). The size of the amplified WT1 mRNA fragment was $461 \mathrm{bp}$. Levels of glyceraldehyde 3-phosphate dehydrogenase (GAPDH) mRNA were measured in the same tubes. 


\section{Co-immunoprecipitation studies}

MCF-7 cells were plated in $100 \mathrm{~mm}$ dishes and transiently transfected with $7 \mu \mathrm{g}$ WT1 $-/-$ expression vector and $7 \mu \mathrm{g} \quad \mathrm{ER} \alpha$ expression vector (or empty vectors) using the jetPEI reagent. After $48 \mathrm{~h}$, cells were lysed and immunoprecipitated with either a WT1 antibody (C-19) or an ER $\alpha$ antibody (MC-20; Santa Cruz Biotechnology) (or normal rabbit serum as a control). Immunoprecipitates were electrophoresed through 8\% SDS-PAGE and immunoblotted with anti-WT1 (F-6; Santa Cruz Biotechnology). Membranes were then washed and incubated with horseradish peroxidase-conjugated Protein A (Amersham Bioscience). Proteins were detected as described above.

\section{EMSAs}

MCF-7 cells were transfected with $7 \mu \mathrm{g}$ ER $\alpha$ expression vector, in the absence or presence of a WT1 - / - vector. After $48 \mathrm{~h}$, cells were lysed and extracts were prepared as described (Werner et al. 1992). The probe used in EMSA was a double-stranded synthetic oligonucleotide containing the consensus estrogen receptor element (ERE) from the vitellogenin gene (Gray \& Gorski 1996). The sequence of the oligomer was: 5'-AATTCGTCCAAAGTCAGGTCACAGTGACCT GATCAAAGTT-3'. The complementary oligonucleotides were annealed in the presence of $100 \mathrm{mM} \mathrm{NaCl}$ at $95^{\circ} \mathrm{C}$ and the double-stranded probe was end-labeled with $\left[\gamma_{-}{ }^{32} \mathrm{P}\right]$ ATP. Binding reactions were performed for $30 \mathrm{~min}$ on ice in a buffer containing $20 \mathrm{mM}$ HEPES, $\mathrm{pH} 7 \cdot 8,100 \mathrm{mM} \mathrm{KCl}, 1 \mathrm{mM}$ dithiothreitol, $1 \mu \mathrm{g}$ poly (dI-dC), $1 \mathrm{mM} \mathrm{ZnCl} 2,10^{5}$ d.p.m. labeled probe, $10 \%$ glycerol and $10 \mu \mathrm{g}$ crude whole cell extract. Changes in mobility were assessed by electrophoresis through native $5 \%$ PAGE gels that were run at $170 \mathrm{~V}$ for $1 \mathrm{~h}$ in $0.5 \times$ TBE.

\section{Results}

Transcription factor WT1 has been identified as a tumor suppressor with potential roles in the etiology of a number of malignancies, including breast cancer (Silberstein et al. 1997, Fabre et al. 1999, Loeb et al. 2001, Zhang et al. 2003). To investigate the effect of WT1 on IGF-IR gene transcription in breast cancer-derived cells, cotransfection experiments were performed in MCF-7 cells using a series of WT1 expression vectors containing or lacking alternatively spliced exons 5 and 9 sequences (Fig. 1A), together with the reporter plasmid $p(-476 /$ +640)LUC, which includes the proximal IGF-IR promoter region. The results of cotransfection experiments are presented in Fig. 1B. All of the four naturally occurring WT1 isoforms significantly repressed IGF-IR promoter activity (39-49\% inhibition). Furthermore, Western immunoblotting of WT1-transfected cells revealed that the transcriptional repressing effect of WT1 was associated with corresponding changes in the levels of endogenous IGF-IR protein (data not shown).

To examine the potential involvement of ER in regulation of IGF-IR gene expression by WT1, IGF-IR levels were measured in MCF-7-derived cells that were selected for reduction of ER $\alpha$ expression (Oesterreich et al. 2001). Specifically, C4 cells were generated by clonal selection of MCF-7 cells that were maintained for 9 months in estrogen-free culture medium. Although C4 cells exhibited a certain variability in ER expression, the passages used in the present study displayed low levels of ER $\alpha$ (Fig. 2A). Results of Western immunoblots using an anti-IGF-IR $\beta$-subunit antibody showed that IGF-IR levels in ER $\alpha$-depleted C4 cells were $42 \cdot 8 \pm 6 \cdot 2 \%$ of control MCF-7 cells (Fig. 2B and G). These data corroborate previous results by Oesterreich et al. (2001). Furthermore, a significant decrease was observed in the levels of the $\sim 205 \mathrm{kDa}$ IGF-IR precursor protein. To investigate whether the WT1 gene is differentially expressed in ER-positive and ER-depleted cells, lysates were prepared from MCF-7 and C4 cells, electrophoresed through 8\% SDS-PAGE gels, and immunoblotted with a WT1 antibody. Results of multiple experiments revealed that WT1 levels in C4 cells were 4.25-fold higher than in MCF-7 cells (Fig. 3). These results are consistent with the possibility that reduced IGF-IR levels in C4 cells result, at least in part, from increased WT1 expression in these cells.

To investigate whether the reduced WT1 levels in MCF-7 cells are due to diminished transcription of the WT1 gene, MCF-7 cells were transiently cotransfected with a luciferase reporter gene under the control of the WT1 promoter, along with an ER $\alpha$ expression vector. The WT1 promoter construct, extending from -873 to +425 relative to the major human transcription start site, has been shown to contain all of the cis-elements required for transcriptional activity in cultured cells (Campbell et al. 1994). Results of coexpression experiments showed that ER $\alpha$ induced a $33 \pm 14 \cdot 8 \%$ decrease in WT1 promoter activity which most probably leads to a reduction in WT1 protein levels (Fig. 4, compare lanes 1 and 3). Estradiol treatment (100 nM) had a marginal effect on WT1 promoter activity in ER $\alpha$-transfected cells (lane 3 vs 4). Similarly, estradiol induced a $28 \pm 1 \%$ reduction in WT1 promoter activity in cells transfected with vector only (lane 1 vs 2).

The potential regulation of WT1 gene expression by estradiol in breast cancer cells was further assessed by treating MCF-7 and C4 cells with increasing concentrations of estradiol for $24 \mathrm{~h}$, followed by immunoblotting of cellular extracts with a WT1 antibody. As shown in Fig. 5A and $\mathrm{B}$, estradiol induced a dose-dependent decrease in WT1 levels in C4 cells $(74 \cdot 5 \pm 11 \cdot 4 \%$ of 


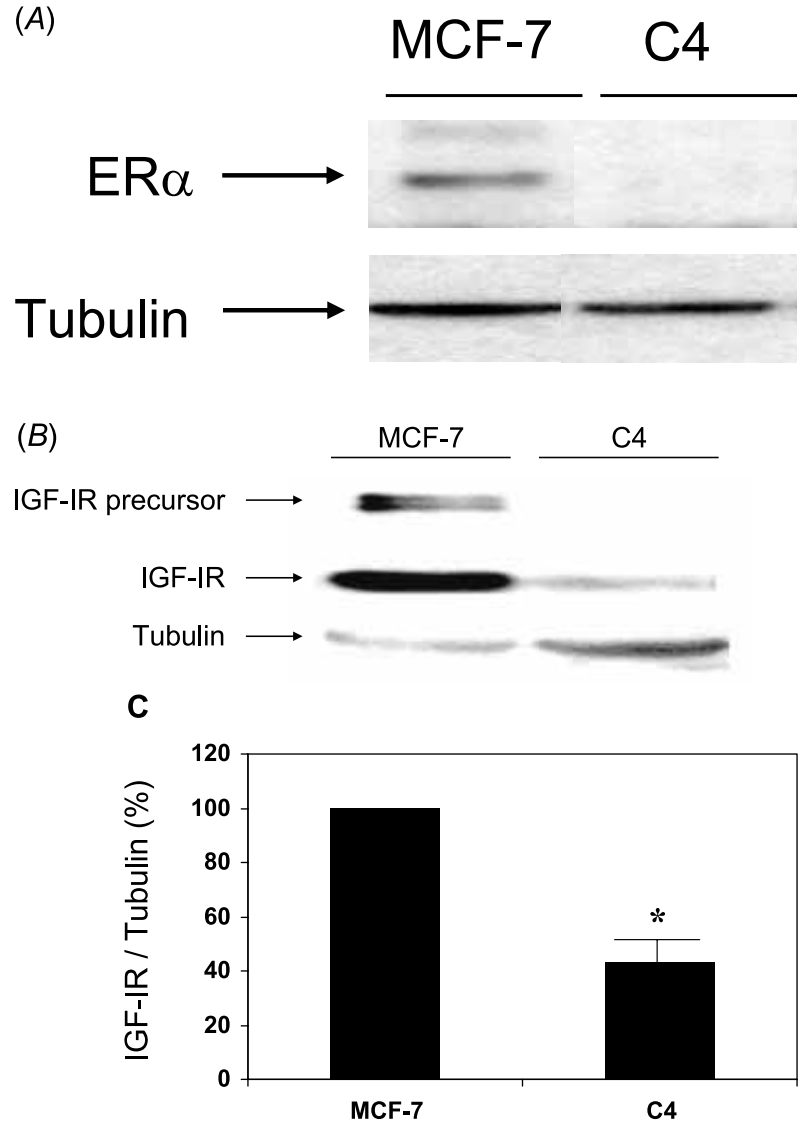

Figure 2 IGF-IR expression in MCF-7 and C4 breast cancer cell lines. Untreated MCF-7 and C4 cells were lysed as described in Materials and methods, cellular extracts $(80 \mu \mathrm{g})$ were electrophoresed through $8 \%$ SDS-PAGE, transferred to nitrocellulose membranes, and blotted with anti-ER $\alpha(A)$ and anti-IGF-IR- $\beta$ (B) antibodies. The position of the $\sim 68 \mathrm{kDa} E R \alpha$ as well as the positions of the $\sim 205 \mathrm{kDa}$ IGF-IR precursor and $\sim 97 \mathrm{kDa}$ IGF-IR $\beta$-subunit proteins are denoted by the arrows. Membranes were re-probed with a tubulin antibody. (C) Densitometric scanning of the IGF-IR band normalized to the corresponding tubulin band. Bars are means \pm S.E.M. $(n=4$ independent experiments). ${ }^{*} P<0.05$ vs MCF-7 cells.

basal at $10 \mathrm{nM}$ estradiol, and $50 \cdot 6 \pm 12 \cdot 9 \%$ of basal at a concentration of $100 \mathrm{nM}$ ). The opposite effect was observed in MCF-7 cells, with hormonal treatment inducing a dose-dependent increase in WT1 levels $(\sim 2 \cdot 3$-fold increase at $10 \mathrm{nM}$ estradiol and $\sim 3 \cdot 6$-fold increase at $100 \mathrm{nM})$. To examine whether the changes in WT1 levels were associated with corresponding changes in WT1 mRNA levels, semiquantitative RT-PCR measurements were performed. Results obtained revealed that estradiol $(100 \mathrm{nM})$ induced a $\sim 52 \%$ decrease in WT1 mRNA levels in C4 cells, whereas the same hormonal dose resulted in a $\sim 2$-fold stimulation of WT1 mRNA levels in MCF-7 cells
$(A)$

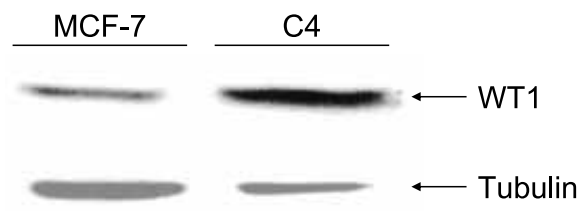

(B)

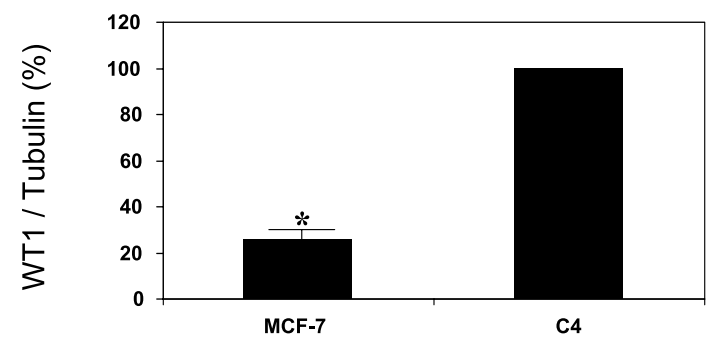

Figure 3 WT1 expression in MCF-7 and C4 breast cancer cells. (A) MCF-7 and C4 cells were maintained as described in Materials and methods. Cells were harvested and cellular pellets were lysed in the presence of protease inhibitors. Equal amounts of protein $(80 \mu \mathrm{g})$ were separated through $8 \%$ SDS-PAGE, transferred and blotted with WT1 and tubulin antibodies. The position of the $\sim 52 \mathrm{kDa}$ WT1 band is indicated. (B) WT1 and tubulin bands were quantitated by densitometric scanning and expressed as WT1 values normalized to tubulin. Bars are means \pm S.E.M. ( $n=5$ independent experiments). ${ }^{\star} P<0.05$ vs $\mathrm{C} 4$ cells.

(Fig. 5C). No changes were seen in GAPDH mRNA levels (data not shown).

To assess the potential functional interactions between $\mathrm{ER} \alpha$ and WT1 in transcriptional regulation of the IGF-IR gene, triple cotransfection experiments were performed in MCF-7 cells using an ER $\alpha$ expression vector, in the absence or presence of WT1 $-/-$ or WT1 $-/+$ expression vectors, along with the IGF-IR reporter plasmid. Expression of ER $\alpha$ stimulated IGF-IR promoter activity by $\sim 1 \cdot 8$-fold whereas coexpression of WT1 abolished the effect of ER $\alpha$ (Fig. 6, lanes 1-4). Furthermore, to examine the ability of WT1 to counteract the estrogen-stimulated increase in IGF-IR promoter activity, triple cotransfections were performed as described above followed by estradiol treatment $(100 \mathrm{nM})$ for $24 \mathrm{~h}$. Estradiol further enhanced IGF-IR promoter activity by $\sim 1.75$-fold (compared with cells transfected with ER $\alpha$ but without hormonal treatment, lane 6 vs 2 in Fig. 6), whereas WT1 $-/-$ and $-/+$ significantly reduced the estrogen-induced stimulation (lanes 7 and 8 vs 6).

To investigate whether the functional interactions between WT1 and ER $\alpha$ in transcriptional control of the IGF-IR gene are associated with physical interactions between both proteins, co-immunoprecipitation assays were performed using extracts of MCF-7 cells that were transfected with expression vectors encoding ER $\alpha$ and WT1 $-/-$ (or empty vectors, to assess the association between the endogenous proteins). Forty-eight hours 


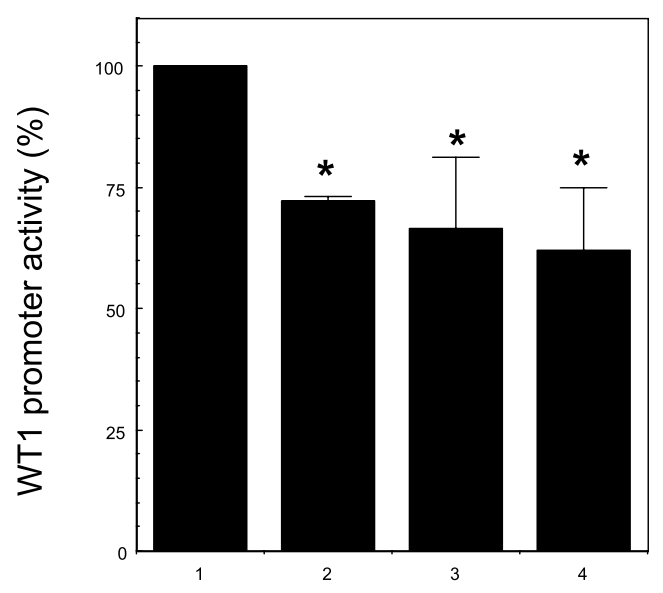

\begin{tabular}{|l|c|c|c|c|}
\hline WT1 promoter & + & + & + & + \\
\hline ER $\alpha$ & - & - & + & + \\
\hline Estradiol $(100 \mathrm{nM})$ & - & + & - & + \\
\hline
\end{tabular}

Figure 4 Regulation of WT1 promoter activity by ER $\alpha$. MCF-7 cells were grown in DMEM with $10 \%$ FBS and transfected with $1.5 \mu \mathrm{g} \mathrm{WT1}$ promoter-luciferase reporter plasmid, along with $0.8 \mu \mathrm{g}$ ER $\alpha$-encoding expression vector (or empty pSG5 vector) and $0.2 \mu \mathrm{g} \mathrm{pCMV} \beta$. After $24 \mathrm{~h}$ cells were treated with estradiol (100 nM), or left untreated. After an additional $24 \mathrm{~h}$ cells were harvested and the levels of luciferase and $\beta$-galactosidase were measured. Promoter activities are expressed as luciferase values normalized for $\beta$-galactosidase. A value of $100 \%$ was given to the promoter activity in the absence of $E R \alpha$ expression vector. Results are means \pm S.E.M. of four independent experiments, performed in duplicate dishes. ${ }^{*} P<0.05$ vs cells transfected with empty vector (lane 1).

after transfection, cells were lysed and immunoprecipitated with anti-WT1 or anti-ER $\alpha$ (or normal rabbit serum). Precipitates were electrophoresed through 8\% SDS-PAGE, transferred to nitrocellulose membranes, and blotted with a second WT1 antibody. Results obtained showed that immunoblotting with anti-WT1 identified the $\sim 52 \mathrm{kDa}$ protein in anti-ER $\alpha$ immunoprecipitates of both ER $\alpha$ /WT1-transfected and mocktransfected cells (Fig. 7A). No WT1 was detected in control samples precipitated with preimmune rabbit serum.

Finally, to determine whether the physical interactions between WT1 and ER $\alpha$ can affect the ability of ER $\alpha$ to bind to the IGF-IR promoter, EMSA assays were performed using cellular extracts of MCF-7 cells that were transfected with an ER $\alpha$ expression vector, in the absence or presence of a WT1 - / - vector. A labeled double-stranded synthetic oligonucleotide containing a consensus ERE was employed for this purpose. Incubation of this probe with extracts of ER $\alpha$ transfected cells resulted in massive binding to the ERE element (Fig. 7B). Cells that were transfected with both

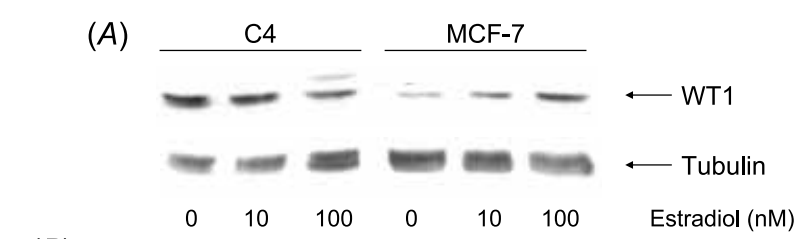

(B)
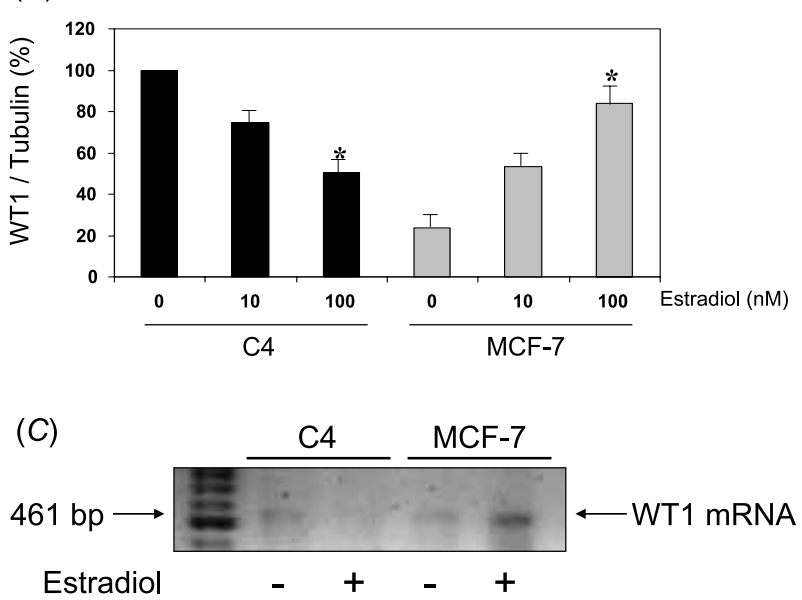

Figure 5 Regulation of WT1 levels by estradiol. (A) MCF-7 and C4 cells were incubated with 0,10 , or $100 \mathrm{nM}$ estradiol for $24 \mathrm{~h}$, followed by Western analysis of WT1 expression. Blots were re-probed with a tubulin antibody. (B) Scanning densitometry of the WT1 bands normalized to the corresponding tubulin bands. The bar graph summarizes the results of three independent experiments, performed in duplicate dishes. ${ }^{*} P<0.05$ vs untreated cells. (C) RT-PCR analysis of WT1 mRNA levels. MCF-7 and C4 cells were incubated with $100 \mathrm{nM}$ estradiol for $24 \mathrm{~h}$, after which total RNA was prepared and WT1 mRNA levels were evaluated by RT-PCR analysis.

$\mathrm{ER} \alpha$ and WT1 - / - displayed a slowly migrating complex, which most probably results from the formation of a high molecular weight multimer involving $\mathrm{ER} \alpha$ and WT1. The intensity of the shifted band was largely diminished, suggesting that the affinity of the $\mathrm{ER} \alpha-\mathrm{WT} 1$ complex to the ERE was reduced.

\section{Discussion}

The IGF system has an important role in mammary gland growth as well as in breast cancer development and progression. IGF-IR, which mediates the biological actions of both endocrine and locally synthesized IGF-I and IGF-II, has been shown in most studies to be largely overexpressed in breast tumors (Happerfield et al. 1997, Surmacz 2000, Yee \& Lee 2000). Recent reports, however, suggested that transition to advanced metastatic stages is associated with a significant reduction in IGF-IR levels (Schnarr et al. 2000, Voskuil et al. 2004). A potential paradigm that may explain the reduced IGF-IR levels in postmitotic terminally differentiated 


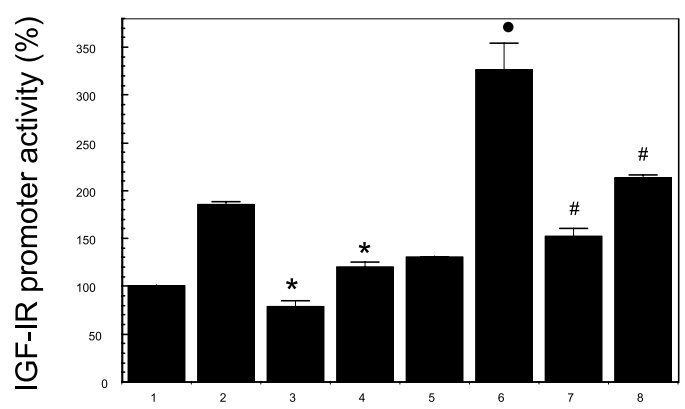

\begin{tabular}{|l|c|c|c|c|c|c|c|c|}
\hline IGF-IR promoter & + & + & + & + & + & + & + & + \\
\hline ER $\alpha$ vector & - & + & + & + & - & + & + & + \\
\hline WT1 -/- vector & - & - & + & - & - & - & + & - \\
\hline WT1 -/+ vector & - & - & - & + & - & - & - & + \\
\hline Estradiol & - & - & - & - & + & + & + & + \\
\hline
\end{tabular}

Figure 6 Functional interactions between ER $\alpha$ and WT1 in transcriptional regulation of the IGF-IR promoter. MCF-7 cells were grown in DMEM with $10 \%$ FBS and cotransfected with $1 \mu \mathrm{g} \mathrm{p}(-476 /+640)$ LUC IGF-IR reporter plasmid together with $1.3 \mu \mathrm{g}$ ER $\alpha$ expression vector (or empty pSG5 plasmid) in the presence or absence of $0.5 \mu \mathrm{g} \mathrm{WT1}-/$-or WT1 $-/+$ vectors (or empty pcDNA3) and $\mathrm{pCMV} \beta$ as a control for transfection efficiency. Transfected cells were collected after $48 \mathrm{~h}$ and luciferase and $\beta$-galactosidase values were measured as described (Werner et al. 1993). Lanes 5-8 were treated with $100 \mathrm{nM}$ estradiol during the last $24 \mathrm{~h}$ of the incubation period. Bars are means \pm S.E.M. of four independent experiments performed in duplicate plates. ${ }^{*} P<0.05$ vs cells transfected with $\mathrm{ER} \alpha$ alone (lane 2). $P<0.05$ vs cells transfected with $\mathrm{ER} \alpha$ but without hormonal treatment (lane 2). \#P<0.05 vs cells transfected with $\mathrm{ER} \alpha$ and treated with estradiol (lane 6).

cells, and its deregulated expression in transformed cells, involves the transcriptional suppression of the IGF-IR gene by a family of negative growth regulators, or tumor suppressors (Werner \& Roberts 2003). In the present study we investigated the potential regulation of IGF-IR gene expression in breast cancer cells by the zinc-finger transcription factor WT1, and the functional and physical interactions between WT1 and ER $\alpha$ in control of IGF-IR gene.

WT1 was initially identified as a tumor suppressor gene whose inactivation was associated with the etiology of a number of pediatric kidney malignancies, including Wilms' tumor, WAGR syndrome (Wilms', aniridia, genito-urinary abnormalities, and mental retardation), and Denys-Drash syndrome (Van Heyningen \& Hastie 1992, Rauscher 1993, Little \& Wells 1997). Mutations of WT1 were also demonstrated in other types of cancer, such as mesothelioma, acute myeloid leukemia, ovarian cancer, etc. Consistent with a tumor suppressor role, we demonstrated in early studies that the inhibitory activity of WT1 in osteosarcoma and Wilms' tumor-derived cell lines was associated with transcriptional repression of the strongly antiapoptotic IGF-IR gene (Werner et al. 1993,
(A)

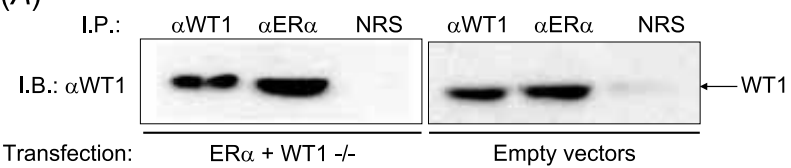

(B)
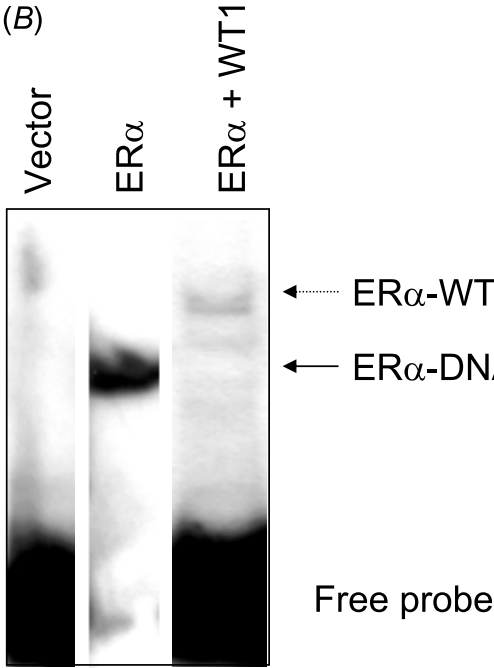

Figure 7 In vivo association between WT1 and ER $\alpha$. MCF-7 cells were transiently transfected with $7 \mu \mathrm{g}$ each of expression vectors encoding ER $\alpha$ and WT1 -/-(A, left panel), or empty expression vectors (right panel), for $48 \mathrm{~h}$ using the jetPEI reagent. Cell lysates were immunoprecipitated with anti-WT1 or anti-ER $\alpha$ (or preimmune normal rabbit serum, NRS), electrophoresed through $8 \%$ SDS-PAGE, blotted onto nitrocellulose membranes, and incubated with a WT1 antibody. The arrow denotes the position of the $\sim 52 \mathrm{kDa}$ WT1 band. I.P., immunoprecipitation; I.B., immunoblotting. (B) EMSA analysis of ER $\alpha$ and WT1 interactions. A double-stranded synthetic oligonucleotide containing the ERE site of the vitellogenin gene was end-labeled with $\left[\gamma-{ }^{32} P\right] A T P$ in the presence of T4 polynucleotide kinase, and employed in EMSA assays with crude whole cell extracts of MCF-7 cells that were transfected with an ER $\alpha$ vector, with or without a WT1 $-/-$ vector. Binding reactions were performed as indicated in Materials and methods. The solid arrow denotes the ER $\alpha-I G F-I R$ promoter complex. The dotted arrow denotes the ER $\alpha-W T 1-I G F-I R$ promoter complex. The migration of the free probe is indicated.

1994, 1995, Idelman et al. 2003). Interestingly, evidence has accumulated in recent years showing that in certain cellular contexts WT1 is required to inhibit apoptosis in vitro and in vivo. This potentially oncogenic role of WT1 has been found to be associated with its capacity to upregulate antiapoptotic genes such as bcl-2 (Mayo et al. 1999).

Likewise, contradictory observations regarding the cellular role of WT1 in the specific context of breast cancer were reported. Consistent with a putative oncogenic role of WT1, high expression levels of the protein were shown to predict a poor prognosis in breast 
cancer patients (Miyoshi et al. 2002). Sequencing analysis of the 10 exons of the WT1 gene in 36 cases of primary breast cancer, however, revealed the absence of mutations (Oji et al. 2004). Furthermore, downregulation of WT1 protein in breast cancer cells using antisense oligodeoxynucleotides led to cellular growth inhibition and reduced cyclin D1 levels (Zapata-Benavides et al. 2002). On the other hand, loss of heterozygosity, a typical feature of most tumor suppressors, of the WT1 gene has been shown to constitute a relatively common event in invasive breast cancer (Fabre et al. 1999). In addition, consistent with a tumor suppressor role, MDA-MB-231-derived clones expressing WT1 in a stable manner exhibited a largely reduced growth ability in soft agar and nude mice (Zhang et al. 2003). The antiproliferative effect of WT1 was associated with a significant decrease in $\beta$-catenin levels.

In the present study we have demonstrated that the four predominant versions of WT1 (out of more than 30 different isoforms that arise through alternative splicing, RNA editing and use of three translation start sites) were able to repress IGF-IR promoter activity in breast cancer-derived cells by 39-49\%. As two of the variants assayed (WT1 $-/+$ and $+/+$ ) included a tripeptide insert (KTS) between zinc-fingers 3 and 4 that was previously shown to impair DNA binding to consensus sequences, we may infer that the inhibitory effect of WT1 on IGF-IR expression is not necessarily associated with direct DNA binding and, therefore, may probably involve protein-protein interactions with IGF-IR promoter transactivators (Werner et al. 1994). Of course, the possibility that the WT1-induced repression of IGF-IR gene expression involves sequence-specific binding of WT1 cannot be discarded.

In view of the fact that IGF-IR gene expression is heavily dependent on the presence of ER (Oesterreich et al. 2001), we evaluated the hypothesis that a potentially novel mechanism of action of WT1 may involve physical interaction with $\mathrm{ER} \alpha$, thus preventing this nuclear receptor from stimulating IGF-IR transcription. Results of co-immunoprecipitation experiments demonstrate that the expressed as well as the endogenous WT1 and $\mathrm{ER} \alpha$ proteins were able to recognize and specifically interact with each other. Furthermore, EMSA experiments indicate that physical interaction between $\mathrm{WT} 1$ and $\mathrm{ER} \alpha$ perturbs the binding of the nuclear receptor to a synthetic ERE site. Further support for this notion is provided by the results of cotransfection studies, showing that both DNA-binding (WT1 - / -) and non DNA-binding (WT1 - /+) isoforms of WT1 were able to abrogate the transactivating effect of ER $\alpha$. We may speculate that reduced ER $\alpha$ binding to ER-response elements located at positions $+272 / 275$ and $+563 / 566$ in the IGF-IR promoter region leads to diminished transactivation, with ensuing decrease in IGF-IR biosynthesis. Alternatively, WT1 binding to specific promoter sequences may interfere with $\mathrm{ER} \alpha$ binding to closely located ER-response elements. In addition, expression of WT1 itself was inhibited by ER $\alpha$. Thus, transfection of an ER $\alpha$ expression vector reduced WT1 promoter activity by $\sim 31 \%$, while WT1 protein levels in ER-positive MCF-7 cells were decreased by $\sim 76 \%$ in comparison with $\mathrm{C} 4$ cells. Combined, these results suggest that $\mathrm{ER} \alpha$ may control WT1 expression at both transcriptional and posttranscriptional levels. Consistent with these results we showed that estradiol treatment induced a dosedependent decrease in WT1 levels in C4 cells whereas, paradoxically, it stimulated WT1 expression in MCF-7 cells. A similar estradiol-induced increase in WT1 levels in MCF-7 cells was recently reported by ZapataBenavides et al. (2002) and these results were interpreted by the authors to suggest that estradiol mainly induces its biological effects in ER-positive, but not ER-negative, breast cancer cells. In addition, the possibility of nongenomic activities of the hormone cannot be discounted.

The ability of WT1 to enhance or suppress IGF-IR gene transcription was recently shown to depend, to a significant extent, on p53 status (Idelman et al. 2003). Thus, WT1 was able to suppress IGF-IR promoter activity in cells lacking p53 or in cells containing a wild-type p53, whereas it was ineffective in suppressing promoter activity in mutant p53-expressing cells. The implications of these complex interactions in breast cancer biology are yet to be elucidated.

In summary, our results demonstrate that transcription factor WT1 suppresses IGF-IR promoter activity in breast cancer cells via a mechanism that involves physical interaction with ER $\alpha$. These findings are consistent with a potential tumor suppressor role for WT1 in breast cancer and suggest that WT1 inactivation in tumoral cells may result in deregulated IGF-IR expression and enhanced mitogenic activation by locally produced and/or circulating IGFs. Measurement of WT1 levels in conjunction with ER assessment might be useful as a prognostic factor in breast cancer patients.

\section{Acknowledgements}

This work was performed in partial fulfillment of the requirements for an MSc degree by $\mathrm{N}$ Reizner in the Sackler Faculty of Medicine, Tel Aviv University. We thank Drs M Eccles, C T Roberts Jr and Y Koch for providing reagents. The authors declare that there is no conflict of interest that would prejudice the impartiality of this scientific work.

\section{References}

Baserga R 1999 The IGF-I receptor in cancer research. Experimental Cell Research $2531-6$. 
Beitner-Johnson D, Werner H, Roberts CT Jr \& LeRoith D 1995 Regulation of insulin-like growth factor I receptor gene expression by Spl: physical and functional interactions of Spl at GC boxes and at a CT element. Molecular Endocrinology 9 1147-1156.

Call KM, Glaser T, Ito CY, Buckler AJ, Pelletier J, Haber DA, Rose EA, Kral A, Yeger H, Lewis WH et al. 1990 Isolation and characterization of a zinc finger polypeptide gene at the human chromosome 11 Wilms' tumor locus. Cell 60 509-520.

Campbell CE, Huang A, Gurney AL, Kessler PM, Hewitt JA \& Williams BRG 1994 Antisense transcripts and protein binding motifs within the Wilms' tumour (WT1) locus. Oncogene $\mathbf{9}$ 583-595.

Dey BR, Sukhatme VP, Roberts AB, Sporn MB, Rauscher FJ III \& Kim S-J 1994 Repression of the transforming growth factor- $\beta 1$ gene by the Wilms' tumor suppressor WT1 gene product. Molecular Endocrinology 8 595-602.

Dong G, Rajah R, Vu T, Hoffman AR, Rosenfeld RG, Roberts CT Jr, Peehl DM \& Cohen P 1997 Decreased expression of Wilms' tumor gene WT1 and elevated expression of insulin like growth factor-II and type 1 IGF receptor genes in prostatic stromal cells from patients with benign prostatic hyperplasia. Fournal of Clinical Endocrinology and Metabolism 82 2198-2203.

Drummond IA, Madden SL, Rohwer-Nutter P, Bell GI, Sukhatme VP \& Rauscher FJ III 1992 Repression of the insulin-like growth factor II gene by the Wilms' tumor suppressor WT1. Science $\mathbf{2 5 7}$ $674-678$.

Fabre A, McCann AH, O'Shea D, Broderick D, Keating G, Tobin B, Gorey T \& Dervan PA 1999 Loss of heterozygosity of the Wilms' tumor suppressor gene (WT1) in in situ and invasive breas carcinoma. Human Pathology 30 661-665.

Gashler AL, Bonthron DT, Madden SL, Rauscher FJ III, Collins T \& Sukhatme VP 1992 Human platelet-derived growth factor A chain is transcriptionally repressed by the Wilms' tumor suppressor WT1. PNAS $8910984-10988$.

Gessler M, Poustka A, Cavence W, Neve RL, Orkin SH \& Bruns GAP 1990 Homozygous deletion in Wilms' tumors of a zinc-finger gene identified by chromosome jumping. Nature 343 774-778.

Gray WG \& Gorski J 1996 Identification and characterization of an estrogen-responsive element binding protein repressed by estradiol. Biochemistry 35 1 1685-11692.

Haber DA, Sohn RL, Buckler AJ, Pelletier J, Call KM \& Housman DE 1991 Alternative splicing and genomic structure of the Wilms tumor gene WT1. PNAS 88 9618-9622.

Hankinson SE, Willett WC, Colditz GA, Hunter DJ, Michaud DS, Deroo B, Rosner B, Speizer FE \& Pollak M 1998 Circulating concentrations of insulin-like growth factor-I and risk of breast cancer. Lancet 351 1393-1396.

Happerfield LC, Miles DW, Barnes DM, Thomsen LL, Smith P \& Hanby AM 1997 The localization of the insulin-like growth factor receptor 1 (IGFR-1) in benign and malignant breast tissue. Fournal of Pathology 183 412-417.

Idelman G, Glaser T, Roberts CT Jr \& Werner H 2003 WT1-p53 interactions in IGF-I receptor gene regulation. Fournal of Biological Chemistry 278 3474-3482.

LeRoith D, Werner H, Beitner-Johnson D \& Roberts CT Jr 1995 Molecular and cellular aspects of the insulin-like growth factor I receptor. Endocrine Reviews 16 143-163.

Little M \& Wells C 1997 A clinical overview of WT1 gene mutations. Human Mutation 9 209-225.

Loeb DM, Evron E, Patel CB, Sharma PM, Niranjan B, Buluwela L, Weitzman SA, Korz D \& Sukumar S 2001 Wilms' tumor suppressor gene (WT1) is expressed in primary breast tumors despite tumor-specific promoter methylation. Cancer Research $\mathbf{6 1}$ 921-925.

Madden SL, Gook DM, Morris JF, Gashler A, Sukhatme VP \& Rauscher FJ III 1991 Transcriptional repression mediated by the WT1 Wilms' tumor gene product. Science 253 1550-1553.
Mayo MW, Wang C-Y, Drouin SS, Madrid LV, Marshall AF, Reed JC, Weissman BE \& Baldwin AS 1999 WT1 modulates apoptosis by transcriptionally upregulating the $b c l-2$ proto-oncogene. $E M B O$ fournal 18 3990-4003.

McConnell MJ, Cunliffe HE, Chua LJ, Ward TA \& Eccles MR 1997 Differential regulation of the human Wilms' tumour suppressor gene (WT1) promoter by two isoforms of PAX2. Oncogene 14 2689-2700.

Mitsiades CS, Mitsiades NS, McMullan CJ, Poulaki V, Shringarpure R, Akiyama M, Hideshima T, Chauhan D, Joseph M, Liberman TA et al. 2004 Inhibition of the insulin-like growth factor receptor-1 tyrosine kinase activity as a therapeutic strategy for multiple myeloma, other hematologic malignancies, and solid tumors. Cancer Cell 5 221-230.

Miyoshi Y, Ando A, Egawa C, Taguchi T, Tamaki Y, Tamaki H, Sugiyama H \& Noguchi S 2002 High expression of Wilms' tumor suppressor gene predicts poor prognosis in breast cancer patients. Clinical Cancer Research 8 1167-1171.

Morris JF, Madden SL, Tournay OE, Cook DM, Sukhatme VP \& Rauscher FJ III 1991 Characterization of the zinc finger protein encoded by the WT1 Wilms' tumor locus. Oncogene 6 2339-2348.

Oesterreich S, Zhang P, Guler RL, Sun X, Curran EM, Welshons WV, Osborne CK \& Lee AV 2001 Re-expression of estrogen receptor $\alpha$ in estrogen receptor $\alpha$-negative MCF-7 cells restores both estrogen and insulin-like growth factor-mediated signaling and growth. Cancer Research 61 5771-5777.

Oji Y, Miyoshi Y, Kiyotoh E, Koga S, Nakano Y, Ando A, Hosen N, Tsuboi A, Kawakami M, Ikegame K et al. 2004 Absence of mutations in the Wilms' tumor gene WT1 in primary breast cancer. Fapanese Fournal of Clinical Oncology 34 74-77.

Pennisi PA, Barr V, Nunez NP, Stannard B \& LeRoith D 2002 Reduced expression of insulin-like growth factor I receptors in MCF-7 breast cancer cells leads to a more metastatic phenotype. Cancer Research 62 6529-6537.

Pollak M 2000 Insulin-like growth factor physiology and cancer risk. European Fournal of Cancer 36 1224-1228.

Rauscher FJ III 1993 The WT1 Wilms' tumor gene product: a developmentally regulated transcription factor in the kidney that functions as a tumor suppressor. FASEB fournal 7 896-903.

Rauscher FJ III, Morris JF, Tournay OE, Cook DM \& Curran T 1990 Binding of the Wilms' tumor locus zinc finger protein to the EGR-1 consensus sequence. Science 250 1259-1262.

Rose EA, Glaser T, Jones C, Smith CL, Lewis WH, Call KM, Minden M, Champagne E, Bonetta L, Yeger H et al. 1990 Complete physical map of the WAGR region of 11 p13 localizes a candidate Wilms' tumor gene. Cell 60 495-508.

Schnarr B, Strunz K, Ohsam J, Benner A, Wacker J \& Mayer D 2000 Down-regulation of insulin-like growth factor-I receptor and insulin receptor substrate-1 expression in advanced human breast cancer. International fournal of Cancer 89 506-513.

Silberstein GB, Van Horn K, Strickland P, Roberts CT Jr \& Daniel CW 1997 Altered expression of the WT1 Wilms' tumor suppressor gene in human breast cancer. PNAS 94 8132-8137.

Surmacz E 2000 Function of the IGF-I receptor in breast cancer. Journal of Mammary Gland Biology and Neoplasia 5 95-105.

Tajinda K, Carroll J \& Roberts CT Jr 1999 Regulation of insulin-like growth factor I receptor promoter activity by wild-type and mutant versions of the WT1 tumor suppressor. Endocrinology $1404713-4724$.

Turner BC, Haffty BG, Narayanan L, Yuan J, Havre PA, Gumbs AA, Kaplan L, Burgaud J-L, Carter D, Baserga R et al. 1997 Insulin-like growth factor-I receptor overexpression mediates cellular radioresistance and local breast cancer recurrence after lumpectomy and radiation. Cancer Research 57 3079-3083.

Van Heyningen V \& Hastie ND 1992 Wilms' tumor: reconciling genetics and biology. Trends in Genetics 8 16-21. 
Voskuil DW, Bosma A, Vrieling A, Rookus MA \& van't Veer LJ 2004 Insulin-like growth factor system mRNA quantities in normal and tumor breast tissue of women with sporadic and familial breast cancer risk. Breast Cancer Research and Treatment $\mathbf{8 4}$ 225-233.

Werner H \& LeRoith D 1996 The role of the insulin-like growth factor system in human cancer. Advances in Cancer Research $\mathbf{6 8}$ 183-223.

Werner H \& Roberts CT Jr 2003 The IGF-I receptor gene: a molecular target for disrupted transcription factors. Genes, Chromosomes and Cancer 36 113-120.

Werner H, Bach MA, Stannard B, Roberts CT Jr \& LeRoith D 1992 Structural and functional analysis of the insulin-like growth factor I receptor gene promoter. Molecular Endocrinology 6 $1545-1558$.

Werner H, Re GG, Drummond IA, Sukhatme VP, Rauscher FJ III, Sens DA, Garvin AJ, LeRoith D \& Roberts CT Jr 1993 Increased expression of the insulin-like growth factor-I receptor gene, IGFIR, in Wilms' tumor is correlated with modulation of IGFIR promoter activity by the WT1 Wilms' tumor gene product. PNAS 90 5828-5832.

Werner H, Rauscher FJ III, Sukhatme VP, Drummond IA, Roberts CT Jr \& LeRoith D 1994 Transcriptional repression of the insulin-like growth factor I receptor (IGF-I-R) gene by the tumor suppressor WT1 involves binding to sequences both upstream and downstream of the IGF-I-R gene transcription start site. Foumal of Biological Chemistry 269 12577-12582.

Werner H, Shen-Orr Z, Rauscher FJ III, Morris JF, Roberts CT Jr \& LeRoith D 1995 Inhibition of cellular proliferation by the Wilms' tumor suppressor WT1 is associated with suppression of insulin-like growth factor I receptor gene expression. Molecular and Cellular Biology 15 3516-3522.

Yee D \& Lee AV 2000 Crosstalk between the insulin-like growth factors and estrogens in breast cancer. Fournal of Mammary Gland Biology and Neoplasia 5 107-115.

Zapata-Benavides P, Tuna M, Lopez-Berestein G \& Tari AM 2002 Downregulation of Wilms' tumor 1 protein inhibits breast cancer proliferation. Biochemical and Biophysical Research Communications 295 $784-790$

Zhang T-F, Yu S-Q Guan L-S \& Wang Z-Y 2003 Inhibition of breast cancer cell growth by the Wilms' tumor suppressor WT1 is associated with a destabilization of $\beta$-catenin. Anticancer Research $\mathbf{2 3}$ $3575-3584$

Received 9 December 2004

Accepted 10 May 2005 